\title{
Identification of Local Wisdom Values in the Village Bejiharjo for Youth Conflict Resolution Education
}

\author{
Lutfi Wibawa \\ Faculty of Education, Yogyakarta State \\ University/Universitas Negeri Yogyakarta \\ Yogyakarta, Indonesia \\ lutfi_wibawa@uny.ac.id
}

\author{
Hiryanto \\ Faculty of Education, Yogyakarta State \\ University/Universitas Negeri Yogyakarta \\ Yogyakarta, Indonesia
}

\begin{abstract}
This article discusses values of local wisdom for youth in conflict resolution Karangmojo Bejiharjo Village District of Gunung Kidul Regency of Yogyakarta Special Region of Indonesia. Bejiharjo village becomes famous because of its natural tourist destinations, namely Gua Pindul (Pindul Cave). Management of tourist destinations by the local community led to conflict on youth. In particular, this article examines values of local wisdom for youth conflict resolution education. Data were collected using focus group discussion (FGD), in-depth interviews, documentation, and observation. The collected data is then analyzed by qualitative descriptive analysis techniques. The main objective of the research and development is to build public awareness in conflict resolution by embedding local widom to the youth group. This research resulted in several findings: 1). The cause of the conflict that occurred youth 2), values of local wisdom in the village Bejiharjo Yogyakarta Indonesia.
\end{abstract}

Keywords-Local Wisdom, Youth education, Conflict resolution of youth

\section{I.INTRODUCTION}

Pindul Cave tourism village located in Bejiharto village, Karangmojo, Gunungkidul Daerah Istimewa Yogyakarta, is a tourist destination that became a phenomenon and attract tourists to visit. Throughout the year 2015 recorded more than 50 thousand tourists who vacation in vilage Pindul Cave tour. This data shows a very significant increase when compared in previous years which only reached the average of 20 thousand to 30 thousand visitors. The large number of visitors is giving the economic impacts of the local people who are active as managers of the tourism conscious group (Pokdarwis).

When the world enters the creative era, a new paradigm in economic development known as "Creative Economy" occurs. This is an economic development concept that focuses on driving the economic through the use of knowledge, education, creativity, and intellectual property that are connected with culture, wisdom, technology and innovation. This covers different industrial sectors, thus, encouraging counties with the need to create economic prosperity and security in their people's living to this developing concept as a guideline for their country development. [6]
Besides giving a positive impact it also gave birth to conflict within the community. So this conflict can have an impact on the harmony of the community and the preservation of local wisdom.

Conflicts differentiate into two types: internal conflicts and external conflicts between Pokdarwis, which involve Pokdarwis in conflict with the public, especially youth groups. Internal conflicts are caused by 1) the big difference in the travel admission price, which is caused by the jockey; the rates vary between Pokdarwis because there is no provision to fixed entry fee for travel; 2) competition for land between Pokdarwis and landowners; 3) the unhealthy competition between Pokdarwis, with every Pokdarwis vying for the most visitors; and 4) the jockeys, who charge their own prices and offer fafors to get tourists.

External conflicts are caused by 1) the lack of direct attention from the government regarding systems management and travel administration; 2) public welfare, which is uneven. Social inequalities are increasingly high, as a result of the lack of equity in the utilization of attraction empowerment; and 3) The mindset of the youth on education, with tourism at Pindul Cave making some youths choose to work there rather than attend school.

Conflicts over are horizontal and involve intercommunity and community groups who are relatively equal. Such conditions have a considerable influence on the convenience and pattern of social relations in society. The conflict between Pokdarwis can be differentiated into the impact in general and specifically the impact among the youth. The overall impact is 1) reduced visitors or tourists, hence reduced revenue; 2) lack of economic equality for people around Pindul, which is associated with the use of Pindul not being involved in the wider community; and 3) social gaps and more visible economic inequality; people who work the Goa Pindul economy will advance, but people who do not work will be increasingly left behind. There is no community empowerment with basic Pindul Cave tourism.

In particular, this conflict also has an impact on youth groups: 1) many youths squander a chance to go to school because they were more interested in working in Goa Pindul; 2) less merging between Pindul and the community, be it public or community organizations, such as youth 
groups; and 3) harmony among youth is reduced because of the conflict surrounding Pindul Cave.[3]

The influence of negative to youth groups has a long-term impact that could disrupt the inheritance of local wisdom values and harmony among generations. So it is very necessary to find an effective strategy for conflict resolution that occurs in youth groups. In this study will be presented an analysis of local wisdom values in Gunungkidul as a foothold in preparing and resolving conflicts that occur. The values of local wisdom are seen as effective instruments to counter, fortify and resolve conflicts among youths who happen in local wisdom-based tourist villages.

\section{RELEVANT THEORY AND LITERATURE}

Scannell [5] mentions aspects that influence individuals in being able to understand and resolve a conflict: communication skills, the ability to appreciate differences, trust in others, and emotional intelligence. Meanwhile, according to Bodine and Crawford [2], formulating some kind of ability that is crucial in fostering conflict resolution initiatives requires orientation ability, ability perceptions, emotional ability, communication skills, creative thinking skills and critical thinking abilities. Orientation ability in conflict resolution includes individual understanding of the conflict and attitudes that show antiviolence, honesty, fairness, tolerance, and self-esteem.

Conflict is ubiquitous in all societies. It is a phenomenon that is inevitable in all human society due to differences in interests, goals, values and aims among people. Most conflicts arise in the basic units of society such as within families, clans, villages, locations or other small units. [1]

Conflict transformation and conflict resolution work in conjunction with conflict prevention. While prevention entails maintaining peace before and after violence by correctly interpreting and acting upon early warning signs, conflict transformation involves shifting existing violence into constructive dialogue. Non-violent modes of conflict resolution can then be applied to achieve peace and prevent future conflicts through the use of early warning systems (EWS) [8]. Although the definitions of the two terms differ, they are often used interchangeably in peace literature and contain similar elements in their modes of application, such as the building of trust and reconstruction (see figure 1 ).

Figure 1

cycle of peace-building during conflict

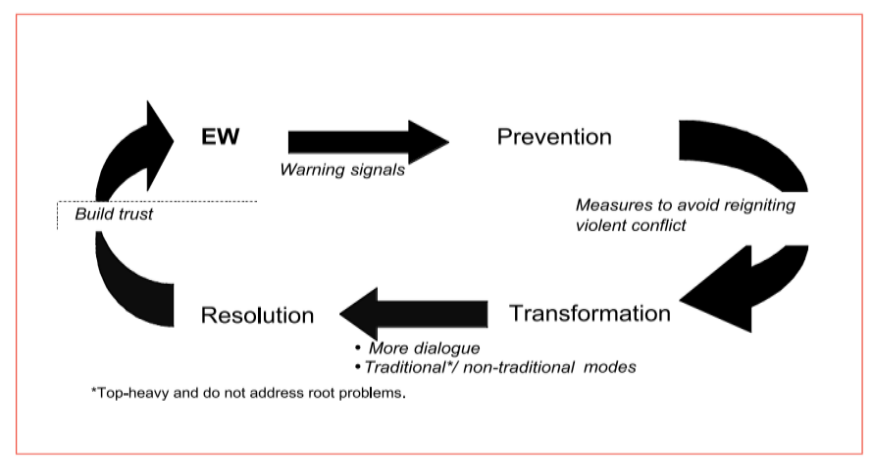

Local wisdom is the knowledge of the provincial gained through their experience and initiation as well as those one that has been passed down from generation to generation. During the transition, the knowledge has been adjusted, adapted, changed and developed. Although something might be lost, new knowledge is acquired in accordance with the era. It can also be said that local wisdom is the use of local wisdom or knowledge to develop local community, resulting in the new set of knowledge [7].

Folklore Research (2007) has summarized the definition of local wisdom into 4 types: 1) local wisdom is an abstract and is related to religion, 2) local wisdom is the potential that protects the community, 3) local wisdom is the body of knowledge and 4) local wisdom is an intellectual capital.

Local wisdom is often also referred to as local policy (local wisdom), local knowledge (local knowledge) or local intelligence (local genius). Local wisdom can be interpreted as a view of life and knowledge as well as various life strategies that manifest the activities undertaken by local communities in answering various problems in meeting their needs. Their fulfillment systems cover all aspects of life, religion, science, economics, technology, social organization, language and communication and art, can be traditions, petatah-petitih or motto of life. The system then becomes part of the way they live. Thanks to the local wisdom, they can live their lives and can even grow sustainably. [4]

[7] Proposed these guidelines to develop local wisdom into creative local development by using these analytical processes; 1) Analyzing basic information in the local context such as population, occupation, income, education. This is basically the analysis of the local information in general in order to understand the context in that particular area to see if there are any problems, weaknesses, strengths, and opportunities for development. 2) Analyzing the community and the society in the area to be developed by evaluating (1) Social unit: analyzing what the society is composed of and what the status and role of each component is. (2) Institution or social organization: analyzing what institution or social organization that area is composed of what role and potential each organization has. (3) Social structure: analyzing the relationship between social units and social institutions to see the connection of each sector in the area. 3) Analyzing local wisdom/resources and their situation in the area to be developed to see what local wisdom/resources are available and in what situation they are. Some might be lost or remain in a good or very good condition. 4) Analyzing problems and potential of the area to see what the weaknesses, strengths, opportunities and threats are in order to understand problematic area and what potential that area has to solve the problems. 5) Analyzing developing opportunities of the area to be developed to see what opportunities are available for the development, what local wisdom/resource should be 
developed and what techniques should be used for the upcoming development.

\section{Method}

Data were collected using focus group discussion (FGD), in-depth interviews, documentation, and observation. The collected data is then analyzed by quantitative and qualitative descriptive analysis techniques. Observation and interview techniques are used to collect local wisdom-values data and conflict-causing data. The data that has been collected is analyzed and described

\section{RESULTS AND DISCUSSION}

Bejiharjo is a village in Karangmojo sub-district, Gunung Kidul, Daerah Istimewa Yogyakarta, Indonesia. Bejiharjo consists of 20 hamlets covering Grogol I, Grogol II, Grogol III, Grogol IV, Grogol V, Grogol VI, Gunungsari, Kulwo, Banyubening I, Banyubening II, Ngringin, Karanglor, Karangmojo, Bulu, Gelaran I, Gelaran II, Sokoliman I , Sokoliman II, Gunungbang, and Seropan. Identified local wisdom can be described in the following sections.

\section{Seni Gamelan/Karawitan}

Seni Gamelan/Karawitan, Gamelan is a set of original Indonesian art instruments consisting of kendang, rebab, celempung, gambang, gong and seruling bambu. For Javanese gamelan people is also a philosophy of the view of life between harmony between the physical and the spiritual, that is the abandon in speaking and acting so as not to create explosive expression and tolerance among others.

The word karawitan comes from the word rawit which means smooth, soft, lungit. Karawitan means the subtlety of taste embodied in the art of gamelan. Karawitan / gamelan can stand alone or accompany the art pedhalangan, vocal art, or art of dance.

It is necessary to preserve and cultivate traditional musical instruments especially Gamelan, because the many modern musical instruments that emerge not become an obstacle for people in Bejiharjo to develop gamelan culture. This activity is intended to keep preserving the culture of gamelan music art in Indonesia so as not to fade and be labeled as cultural music arts by other countries. Another way to introduce the art of gamelan music to the younger generation as early as possible and always try to preserve the activities that are able to preserve the tradition.

Bejiharjo community in the development of gamelan art that is learning to play gamelan music instrument, citizens antusisme seen with the emergence of groups who want to learn, from children to parents with the instructor / tutor artists from the surrounding area. According to local people local wisdom gamelan art contains meaning for their life, which is a mixture of musical instruments full of meaning and dilatari with various philosophy.

\section{Gejoh Lesung/Alat Musik Tradisional}

Gejoh Lesung /Alat Musik Tradisional, Gejoh lesung, One of the traditional art from Yogyakarta. In the past, the dimple was used to separate the rice from the stem. The development of the era is easy for humans to cultivate rice quickly. Mashing in the dimple is considered less effective. Gejoh lesung often sounded during the lunar eclipse, this tradition is still done when there is a traditional art festival, clean village, or village races. Characteristic of this art is alu and lesung. Alu is a tool made of wood to pound, while the lesung (shaped like a boat) is used to separate the rice from the stalk. Usually this alu will be played by seven to eight people. To make it more interesting, this tradition has been combined with Javanese songs.

\section{Rasulan/Bersih Desa}

Rasulan is one of the community culture in Gunungkidul area which is also carried out in Bejiharjo village, elsewhere there is called clean hamlet / village or merti hamlet / village. Rasulan is a form of gratitude farmers to the Creator of Allah SWT over the overflow of crops for a year. Rasulan implemented after harvest or usually after the dry season comes. Rasulan implemented by padukuhan / hamlet or some group of hamlet / hamlet, every padukuhan or group of hammer usually have certain special day to implement Rasulan. In filling the activities of Rasulan also performed various traditional art performances ranging from reog, doger, kethoprak, wayang kulit, cultural carnival, gunungan and also to sports activities such as Volleyball and football. The most special procession is the ingkung ayam kampung and nasi uduk which according to the philosophy of Java many meanings about nasi uduk (sekul suci), ingkung ayam (ulam sari).

Apart from the arts and cultural activities above Rasulan have a high enough value of worship, such as hospitality and shodaqoh. When Rasulan arrived the celebrating citizen clearly invited friends and relatives as well as definitely at home also preparing the most special food to be served to the guests. In Islam mentions "Whoever is happy to be cleansed rizki and end of his death (lengthened his age), then let him connect (rope) friendship." (Profet Muhammad). Profet Muhammad : Will you show me the most noble character in the world and the Hereafter? "Forgive the one who despises you, gives the one who blocks you and connects the silaturrahim of the person who decides you ", (HR. Baihaqi). Not necessarily we can invite friends or relatives with prepared special dishes 
to be enjoyed as in the event Rasulan, this culture is extraordinary value worship. Society flocked to attend friends or relatives who are Rasulan also we can as a relationship.

The people who prepare the dishes do not intend to be discarded or just for display but intend to be served to the guests. "There is no good in most of their whisperings, save the whispers of those who enjoin (give) alms, or do ma'ruf or make peace between men, and whoever does so by seeking the pleasure of Allah, Will give him a great reward. " (QS An Nisaa [4]: 114). Bejiharjo people still maintain this local wisdom, even they give meaning of apostles are: 1. Being Gratitude of overflow fortune harvest, 2. Form of friendship with friends and family, 3. Form of shodaqoh.

The younger generation that is actually not part of this cycle of conflict will gradually enter it and be affected. Therefore, there is a need for concrete activities to equip and fortify young people in the village of Bejiharjo not directly involved in the conflict, which could even offer a solution to the conflict. Thus, there is the need for a comprehensive understanding of the younger generation associated with conflict resolution. Conflict resolution consists of (1) action to unravel a problem, (2) a solution, and (3) the elimination or removal of problems. These are joint problem-solving actions and involve solving a problem together. Conflict resolution is an attempt to address the causes of conflict and to establish new, long-lasting relationships between warring groups. Conflict resolution is the ability to resolve differences with others and is an important aspect of social and moral development that requires skill and judgment to negotiate, achieve compromise, and develop a sense of justice.

In particular, this article will examine the factors that cause conflict, the impact of conflict on young people, and what can be done to reduce the impact of conflict. The main objective of the research is to build public awareness of the conflict without a negative impact on youth. Thus, the community formed a group of people who conducted prevention activities as conflict resolution agents.

Local wisdom becomes the main ingredient in finding conflict solutions that occur, as well as a stronghold to increase the resilience of youth groups in facing conflict. So the youth are not easily hooked and participate in conflict areas.

\section{CONCLUSION}

Conflict that occurred in the village of pindul cave tourism village Bejiharjo, Karangmojo district Gunungkidul Special Region of Yogyakarta, giving side effects to youth groups. To resolve conflicts and keep young people from becoming involved and affected by conflict, a local wisdom education strategy is needed for youth. So in research with the title "Identification of Local Wisdom Values in the village Bejiharjo for youth education Conflict Resolution", Has managed to find some conclusions:

First, local wisdom values include: local arts and culture (gamelan and karawitan art, Gejlok lesung, Reog), gotong royong, traditions (Rasulan / Bersih Desa), Religious society, life integrates with nature. Second, community conflicts affecting youth groups need a conflict resolution approach based on local wisdom values.

Third, based on the results of discussions and interviews with the community, that the values of existing local wisdom can be used as material to resolve the conflict that occurred. Fourth, the conflict resolution model formulated is conflict resolution training on youth based on local wisdom values. Fifth, conflict resolution training materials include: 1. Local wisdom values as the basis for conflict resolution, 2. Conflict management, 3. Resilience to face pressure, 4. Building awareness of mutual cooperation, 5. Loving nature and living with nature.

\section{REFERENCES}

[1] Francis Kariuki (2015), Conflict Resolution by Elders in Africa : Successes, Challenges and Opportunities https://www.ciarb.org/docs/defaultsource/centenarydocs/speaker-assets/franciskariuki.pdf?sfvrsn $=0$

[2] Jones, Tricia S. \& Kmitta, (2001). School Conflict Management: Evaluating Your Conflict Resolution Education Program. Ohio: Ohio Commission on Dispute Resolution \& Conflict Management.

[3] Lutfi, Hiryanto (2017), Conflict Resolution Youth Village Tourism Cave Tubing Pindul in Yogyakarta, http://www.atlantispress.com/php/pub.php?publication=nfe-16

[4] Permana, Cecep Eka. (2010). Kearifan Lokal Mayarakat Baduy Dalam Mengatasi Mitigasi Bencana. Jakarta: Wedatama Widya Sastra.

[5] Scannell, Mary. 2010. The Big Book of Conflict Resolution Games. United States of America: McGraw - Hill Companies, Inc

[6] Termsak Singsomboon (2014), International Journal of Business Tourism and Applied Sciences, Tourism Promotion And The Use Of Local Wisdom Through Creative Tourism Proces, ICBTS Institute.

[7] Terdchai Chuaybamroong. (2011). Local Wisdom for Creative Community Development. Bangkok : King Prajadhipok's Institute.

[8] United Nations (2003), Youth and Conflict, World Youth Report, http://www.un.org/esa/socdev/unyin/documents/ch14.pdf 